\title{
Structure and variability of a microbial community at a transect crossing a double gyre structure in the northeastern Adriatic Sea
}

\author{
Sandi Orlić, Mirjana Najdek*, Nastjenjka Supić, Ingrid Ivančić, Dragica Fuks, \\ Maria Blažina, Tina Šilović, Paolo Paliaga, Jelena Godrijan, Daniela Marić
}

Center for Marine Research, Ruđer Bošković Institute, G. Paliaga 5, 52210 Rovinj, Croatia

\begin{abstract}
The effect of environmental conditions on bacterial community structures, production and enzymatic activities was studied in the northeastern Adriatic Sea in the late spring of 2009 in waters belonging to the cyclonic gyre (CG)and the anticyclonic gyre (AG), and in waters not affected by the presence of these 2 gyres. The AG and CG were formed in the same pool of warm, low-salinity, nutrient-rich waters characterized by increased autotrophic production and abundance. Differences in bacterial community structures and in intensities of cell-specific prokaryotic production and enzymatic activities indicated that CG and AG were isolated circulation cells in which water resided for different periods of time. Bulk prokaryotic production and enzymatic activities were significantly lower in the region outside the influence of the gyres. Bacterial communities of these waters, particularly in deeper layers, were likely introduced by highsalinity oligotrophic waters from the central Adriatic.
\end{abstract}

KEY WORDS: Gyres - Heterotrophic bacteria - Prokaryotic production - Enzymatic activities · DGGE · Northern Adriatic Sea

\section{INTRODUCTION}

Frontal zones, characterized by sharp gradients of physical properties between distinctive water masses, are important areas of diverse ecological adaptation processes that influence biological activity and the fate of organic carbon (Legendre \& Rassoulzadegan 1996). The biological consequences of such hydrodynamic conditions, especially fertilization, which stimulates primary production, have been thoroughly studied in the Mediterranean (Moran et al. 2001). In response to these conditions, bacteria adapt their production and ectoenzymatic activities (Van Wambeke et al. 2004, 2009, Baltar et al. 2007). The changes in bacterial activity can be significantly correlated with bacterial community structure (Alonso-Sáez et al. 2007), but very similar structures can also express very different patterns of function (Gasol et al. 2009, Baltar et al. 2010).

The ecosystem of the northern Adriatic is under alternating influence of eutrophic low-salinity water originating from the Po delta area, and oligotrophic high-salinity water from the central Adriatic. The spatial extent of the 2 water types shows significant year to year variation (e. g. Supić et al. 2012). Waters originating from the Po delta can accumulate in the northeastern Adriatic in an anticyclonic gyre (AG) whose presence is indicated by a southerly flow in the coastal zone off Istria: the Istrian Coastal Countercurrent (ICCC; Supić et al. 2000). According to monthly averages, the AG, located generally north of $44.5^{\circ} \mathrm{N}$, i.e. 
north of the $50 \mathrm{~m}$ isobath (Fig. 1), appears typically, but not exclusively, in summer and is part of a larger structure, which, besides the AG, includes a large cyclonic gyre (CG) in the northernmost Adriatic (Krajcar 2003). Surface waters of the 2 gyres are less saline and generally warmer than waters south of the area in which they appear (Krajcar 2004). In 2003, the existence of the 2 gyres was documented in both winter (Kuzmić et al. 2007) and summer (Lyons et al. 2007).

In spring 2009, inspection of satellite data suggested that low salinity waters from the River Po were accumulating in the northeastern Adriatic, coming up against more saline waters originating from the central Adriatic. A multi-disciplinary sampling was performed along a transect in the region to investigate whether presence of this closed circulation cell had an impact on the structures, production and enzymatic activities of bacterial communities. Similar investigations are frequently carried out in the Mediterranean Sea (e. g. Christaki et al. 2011) but this is the first study of its kind in the northern Adriatic.

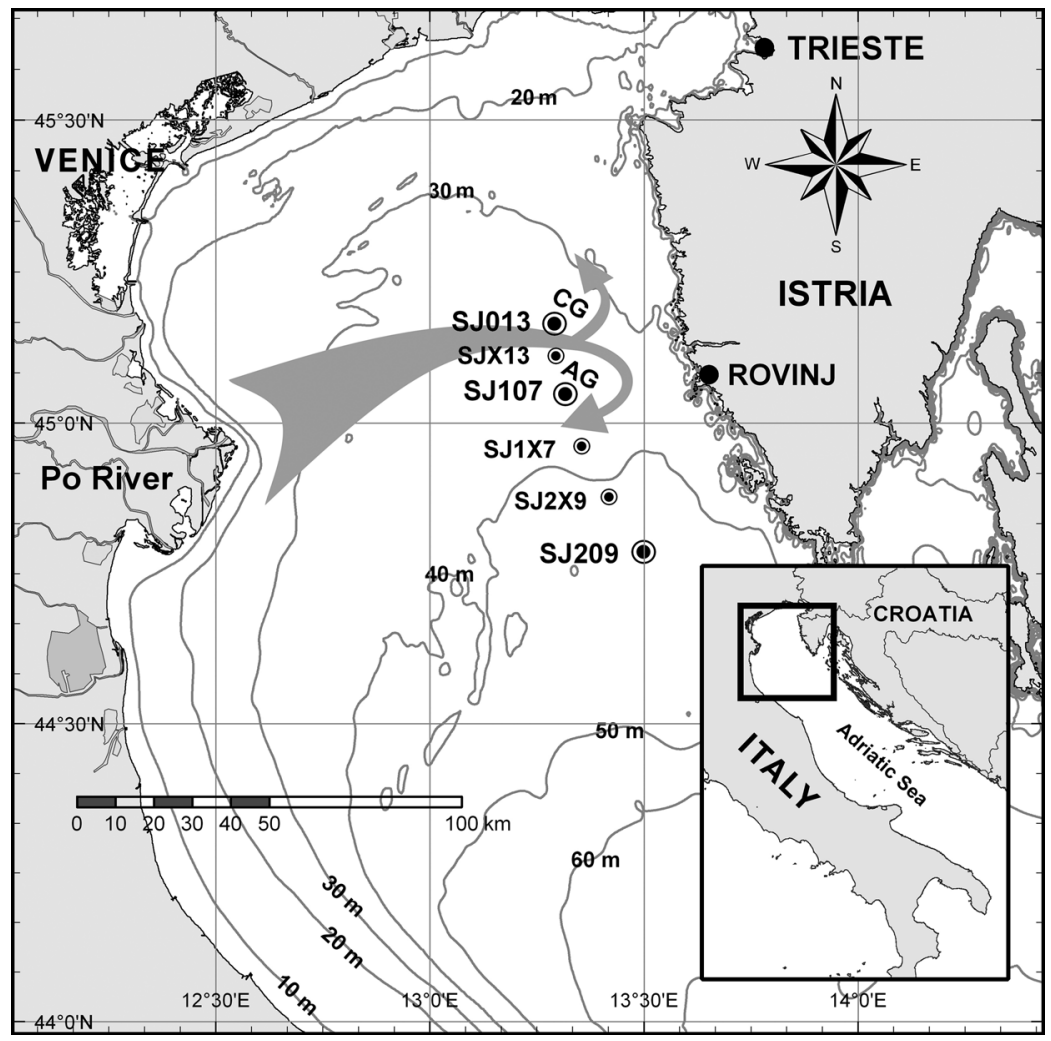

Fig. 1. Location of sampling stations in the northeastern Adriatic Sea and positions of the cyclonic (CG) and anticyclonic (AG) gyres. (O) 'Main stations' where water samples were collected and CTD data were recorded; $(\odot)$ stations where only CTD data were recorded. Grey arrows show hypothetical paths of waters originating from the River Po. Contour lines show isobaths

\section{MATERIALS AND METHODS}

\section{Sampling strategy and basic parameters}

Sampling was performed along a transect in the coastal zone off Istria during a cruise on 18 June 2009 aboard RV 'Vila Velebita'. The transect comprised 6 stations (Fig. 1, Table 1), at which conductivity, temperature and depth (CTD) data were recorded (SeaBird Electronic SBE 25). Additionally, at each of 3 'main stations' SJ013, SJ107 and SJ209, 4 seawater samples were collected by SCUBA divers into horizontally placed Niskin samplers. Except for the surface, the choice of sampling points was made to correspond to depths of salinity gradients as revealed by the CTD profiler (see Table 2 for depths of individual samples).

Dissolved inorganic nitrogen (DIN; i.e. nitrates, nitrites, and ammonia), orthophosphate and chlorophyll a (chl a) concentrations were determined spectrophotometrically and fluorometrically, respectively, following standard procedures (Strickland \& Parsons
Table 1. Latitudes, longitudes and depths (D) of sampling stations in the northeastern Adriatic Sea, with sampling times $(t)$

\begin{tabular}{|lcccc|}
\hline Stn & Latitude & Longitude & D (m) & $t$ (UTC) \\
\hline SJ013 & $45.165^{\circ} \mathrm{N}$ & $13.292^{\circ} \mathrm{E}$ & 34 & $10: 15 \mathrm{~h}$ \\
SJ1X3 & $45.104^{\circ} \mathrm{N}$ & $13.303^{\circ} \mathrm{E}$ & 34 & $10: 50 \mathrm{~h}$ \\
SJ107 & $45.048^{\circ} \mathrm{N}$ & $13.317^{\circ} \mathrm{E}$ & 37 & $11: 30 \mathrm{~h}$ \\
SJ1X7 & $44.957^{\circ} \mathrm{N}$ & $13.376^{\circ} \mathrm{E}$ & 39 & $12: 30 \mathrm{~h}$ \\
SJ2X9 & $44.866^{\circ} \mathrm{N}$ & $13.440^{\circ} \mathrm{E}$ & 40 & $13: 30 \mathrm{~h}$ \\
SJ209 & $44.787^{\circ} \mathrm{N}$ & $13.500^{\circ} \mathrm{E}$ & 42 & $14: 30 \mathrm{~h}$ \\
\hline
\end{tabular}

1972). Transparent exopolymer particle (TEP) concentration was determined spectrophotometrically according to Passow \& Alldredge (1995).

\section{Geostrophic currents}

The 1 to $25 \mathrm{~m}$ layer density data were used to compute dynamic depths of the 25 dbar surface at all 6 
Table 2. Summary characteristics of sampling stations SJ013, SJ107 and SJ209: sampling depth (SD), temperature $(T)$, salinity $(\mathrm{S})$, density anomaly $\left(\sigma_{t}\right)$, water type (WT), gyre presence (GP), and label (L). Two water types were recognized: pool waters (P) with $\sigma_{\mathrm{t}}<23$ and denser waters (D) with $\sigma_{t}>23$. Stations SJ013 and SJ107 were located in the cyclonic gyre (CG) and anticyclonic gyre (AG), respectively, and were thus affected by the presence of these gyres (A), while SJ209 was not (N)

\begin{tabular}{|cccccccc|}
\hline \multirow{2}{*}{ Stn } & $\mathrm{SD}(\mathrm{m})$ & $\mathrm{T}\left({ }^{\circ} \mathrm{C}\right)$ & $\mathrm{S}$ & $\sigma_{\mathrm{t}}$ & $\mathrm{WT}$ & $\mathrm{GP}$ & $\mathrm{L}$ \\
\hline SJ013 & 0 & 23.23 & 33.28 & 22.59 & $\mathrm{P}$ & $\mathrm{A}$ & PCG1 \\
& 3 & 23.27 & 33.26 & 22.57 & $\mathrm{P}$ & $\mathrm{A}$ & PCG2 \\
& 4.5 & 22.54 & 35.45 & 24.44 & $\mathrm{D}$ & $\mathrm{A}$ & DCG1 \\
& 9 & 20.89 & 37.18 & 26.21 & $\mathrm{D}$ & $\mathrm{A}$ & DCG2 \\
SJ107 & 0 & 23.65 & 33.17 & 22.39 & $\mathrm{P}$ & $\mathrm{A}$ & PAG1 \\
& 5 & 23.48 & 33.21 & 22.47 & $\mathrm{P}$ & $\mathrm{A}$ & PAG2 \\
& 10 & 22.97 & 33.69 & 22.97 & $\mathrm{P}$ & $\mathrm{A}$ & PAG3 \\
& 20 & 16.48 & 37.85 & 27.86 & $\mathrm{D}$ & $\mathrm{A}$ & DAG1 \\
SJ209 & 0 & 22.16 & 37.44 & 26.06 & $\mathrm{D}$ & $\mathrm{N}$ & DN1 \\
& 10 & 21.57 & 37.41 & 26.20 & $\mathrm{D}$ & $\mathrm{N}$ & DN2 \\
& 18 & 20.34 & 37.66 & 26.73 & $\mathrm{D}$ & $\mathrm{N}$ & DN3 \\
& 35 & 15.16 & 37.85 & 28.16 & $\mathrm{D}$ & $\mathrm{N}$ & DN4 \\
\hline
\end{tabular}

stations of the transect and the resulting geostrophic currents between each 2 neighbouring stations (e.g. Supić et al. 2000). Density of the 0 to $1 \mathrm{~m}$ layer was taken to be equal to density at $1 \mathrm{~m}$ depth.

\section{Autotrophic plankton abundance}

Samples for microphytoplankton count were preserved in $2 \%$ (final conc.) neutralized formaldehyde (Throndsen 1978). Sub-samples of $50 \mathrm{ml}$ were gently homogenized, sedimented for $48 \mathrm{~h}$ and analyzed using an inverted microscope (Zeiss Axiovert 200) following the Utermöhl method (Utermöhl 1958). Cells were counted on 2 transects under magnifications of $400 x$ and $200 x$ and the entire chamber was inspected at $100 \times$ for larger species. Cells longer than $20 \mu \mathrm{m}$ were designated as microphytoplankton (Sieburth et al. 1978).

Samples for pico- and nanophytoplankton counts were preserved in $0.5 \%$ glutaraldehyde for $10 \mathrm{~min}$, frozen in liquid nitrogen, and stored at $-80^{\circ} \mathrm{C}$ until analysis. Samples were analyzed using a Partec PAS III flow cytometer, equipped with an Argon laser $(488 \mathrm{~nm})$. Instrumental settings were standardized for all parameters using fluorescence polystyrene calibration beads of 1, 3 and $10 \mu \mathrm{m}$ diameter. Subpopulations of phytoplankton were distinguished by the autofluorescence of the chlorophyll content of the cells (FL3) and the phycoerythrin content of the phycoerythrin-rich cells (FL2), as well as by the cells' forward-angle light scatter (FSC), used as a proxy of their size. These fluorescence signals allowed differentiation of pico- and nanoeukaryotes and cyanobacteria Synechococcus, while Prochlorococcus was not detected. Data were collected in list mode files using FL3 as a trigger parameter and processed using the software FloMax (Partec).

\section{Heterotrophic bacteria and heterotrophic flagellate abundance}

For heterotrophic bacteria abundance (HB), $2 \mathrm{ml}$ of samples were stained with 4,6-diamidino-2phenylindol (1 $\mathrm{gg} \mathrm{ml}^{-1}$ final conc.) for $10 \mathrm{~min}$, and then passed through $0.2 \mu \mathrm{m}$ black polycarbonate fillters (Nuclepore). UV excitation with epifluorescence microscopy (Leitz Laborlux D) was used for counting (Porter \& Feig 1980). At least 500 single cells were counted for each sample at a final magnification of $1000 x$.

For heterotrophic nano- and picoflagellate abundance (HF) $15 \mathrm{ml}$ of samples were filtered through black polycarbonate membrane filters $(0.4 \mu \mathrm{m}$ pore size) and counted after staining with primulin $(250 \mu \mathrm{g}$ $\mathrm{ml}^{-1}$ in $0.1 \mathrm{M}$ Trizma $\mathrm{HCl}, \mathrm{pH}=4.0$ ) for $15 \mathrm{~min}$. The chlorophyll containing cells (i.e. autotrophic flagellates) were not counted as HF (Caron 1983).

\section{Prokaryotic production}

The rate of ${ }^{3} \mathrm{H}$-leucine and ${ }^{3} \mathrm{H}$-thymidine incorporation into macromolecules was measured for estimation of prokaryotic heterotrophic production (Fuhrman \& Azam 1982, Kirchman et al. 1985, Smith \& Azam 1992). Triplicate $(1.7 \mathrm{ml}$ aliquots) samples were incubated with $\mathrm{L}-\left[4,5-{ }^{3} \mathrm{H}\right]$ leucine (spec. activity $>100 \mathrm{Ci} \mathrm{mmol}^{-1}, 20 \mathrm{nM}$ final conc.) or methyl- ${ }^{3} \mathrm{H}$-thymidine (spec. activity $>70 \mathrm{Ci}$ $\mathrm{mmol}^{-1}, 20 \mathrm{nM}$ final conc.) in sterile $2.0 \mathrm{ml}$ microcentrifuge tubes for $1 \mathrm{~h}$ in the dark at in situ temperature. Samples with $100 \%$ TCA added prior to the addition of isotopes served as blanks. Incubation of samples was stopped with addition of $100 \%$ TCA, samples were centrifuged, supernatant was discarded and labelled material was extracted with cold 5\% TCA, then with $80 \%$ ethanol and finally collected by centrifugation. Specific leucine and thymidine incorporation rates were obtained by dividing the average rates per litre by bacterial abundance per litre. 


\section{Enzymatic activities}

Ectoenzymatic activities were measured, in duplicate, aboard the research vessel immediately after sample collection using artificial fluorogenic substrates at saturation concentrations. Activities were determined using the following substrates: 4-methylumbelliferyl phosphate $\left(50 \mu \mathrm{mol} \mathrm{l}^{-1}\right.$ final conc.; Ivančić et al. 2009) for alkaline phosphatase; 4methylumbelliferyl- $\beta$-D-glucopyranoside $\left(25 \mu_{\mathrm{mol}} \mathrm{l}^{-1}\right.$ final conc.; Hoppe 1983) for $\beta$-D-glucosidase, and Lleucine-4-methylcoumarinile-7-amide $\left(250 \mu \mathrm{mol} \mathrm{l} \mathrm{l}^{-1}\right.$ final conc.; Hoppe et al. 1988) for leucine aminopeptidase. Measurements of $\beta$-glucosidase were carried out in unfiltered water (mainly heterotrophic bacteria express this enzyme) while for phosphatase and aminopeptidase 2 pre-filtered fractions $(<0.2$ and $<3 \mu \mathrm{m}$ ) were analyzed. The 0.2 to $3 \mu \mathrm{m}$ fraction contained heterotrophic bacteria and picocyanobacteria, and hence activities in this fraction are referenced as prokaryotic activities. Incubation was performed in the dark at the in situ temperature and $\mathrm{pH}$ to obtain maximum activity in ambient conditions. Fluorescence was measured immediately after substrate addition and after incubation (of up to 3 to $5 \mathrm{~h}$ ) using a Turner TD-700 fluorometer with excitation wavelength of $365 \mathrm{~nm}$ and emission at $455 \mathrm{~nm}$ for methylumbelliferyl, and excitation at $380 \mathrm{~nm}$ and emission at $440 \mathrm{~nm}$ for methylcoumarin. Activities of the respective enzymes were calculated as the difference of these 2 measurements divided by the incubation time after calibration of the fluorometer with methylumbelliferone and methylcoumarin. Blanks prepared in autoclaved sea water did not show any changes in fluorescence after incubation. Detection limit of enzymatic activities for this set of measurements was $0.009 \mu \mathrm{mol} \mathrm{l}^{-1} \mathrm{~h}^{-1}$.

\section{Bacterial community structure}

For DGGE analysis, 51 of seawater was collected to $0.2 \mu \mathrm{m}$ pore diameter filters (Nuclepore PC) with a vacuum pump at $20 \mathrm{kPa}$. Filters were placed in cryovials, filled with $1.8 \mathrm{ml}$ of lysis buffer (40 mM EDTA, $50 \mathrm{mM}$ Tris- $\mathrm{HCl}, 0.75 \mathrm{M}$ sucrose) and stored at $-80^{\circ} \mathrm{C}$. Nucleic acid extraction began by adding lysozyme $\left(1 \mathrm{mg} \mathrm{ml}^{-1}\right)$ to the filter and incubating at $37^{\circ} \mathrm{C}$ for $45 \mathrm{~min}$. Subsequently, proteinase K $0.2 \mathrm{mg}$ $\mathrm{ml}^{-1}$ ) and sodium dodecyl sulphate (SDS, $1 \%$ ) were added, and the filter was incubated at $55^{\circ} \mathrm{C}$ for $1 \mathrm{~h}$. The lysate was recovered from the filter and the filter was rinsed with $1 \mathrm{ml}$ of lysis buffer. The pooled lysates were then extracted twice with an equal amount of phenol:chloroform:isoamyl alcohol (25:24:1, $\mathrm{pH}$ 8) and once with an equal amount of chloroform:isoamyl alcohol (24:1). The aqueous phase was spun down in a microconcentrator (Centricon100, Millipore), washed with sterile TE buffer several times and reduced to a volume of 100 to $200 \mu$ l. Nucleic acid extracts were stored at $-70^{\circ} \mathrm{C}$.

Microbial DNA (1 ng) was used as template for polymerase chain reaction (PCR) amplification of bacterial $16 \mathrm{~S}$ rDNA. The reactions $(50 \mu \mathrm{l})$ contained $200 \mu \mathrm{M}$ of each of the deoxynucleoside triphosphates, $0.3 \mu \mathrm{M}$ of each of the primers, $1.5 \mathrm{mM} \mathrm{MgCl}_{2}$, 1× PCR buffer and 1 U Taq DNA polymerase (Applied Biosystems). Bacterial specific primer 358f, with a 40 bp GC clamp, and the universal primer 907r, which amplifies a 550 bp DNA fragment of bacterial 16S rDNA, were used. The PCR was performed with a Verity Thermal Cycle (Applied Biosystems) under the following conditions: $5 \mathrm{~min}$ at $94^{\circ} \mathrm{C}_{i} 10 \mathrm{cy}$ cles each for $1 \mathrm{~min}$ at $94^{\circ} \mathrm{C}, 3 \mathrm{~min}$ at $72^{\circ} \mathrm{C} ; 20$ cycles each $1 \mathrm{~min}$ at $94^{\circ} \mathrm{C}, 1 \mathrm{~min}$ at $55^{\circ} \mathrm{C}$ and $3 \mathrm{~min}$ at $72^{\circ} \mathrm{C}$, plus a final extension at $72^{\circ} \mathrm{C}$ for $5 \mathrm{~min}$. PCR products were verified and quantified by agarose gel electrophoresis ( $1 \%$ agarose gel). The Dcode universal mutation detection system (Bio-Rad Laboratories) was used for DGGE analysis of the PCR products. A $6 \%$ polyacrylamide gel with a gradient of DNA-denaturant agent was cast by mixing solutions of $30 \%$ and $60 \%$ denaturant agent (100\% denaturant agent is $7 \mathrm{M}$ urea and $40 \%$ deionized formamide). $800 \mathrm{ng}$ of PCR product was loaded for each sample and the gel was run at $100 \mathrm{~V}$ for $16 \mathrm{~h}$ at $60^{\circ} \mathrm{C}$ in $1 \times \mathrm{TAE}$ buffer $(40$ $\mathrm{mM}$ Tris $[\mathrm{pH} 7.4], 20 \mathrm{mM}$ sodium acetate, $1 \mathrm{mM}$ EDTA). Gels were stained with the nucleic acid stain SYBR Gold Safe (Molecular Probes) for $20 \mathrm{~min}$, rinsed with $1 \times$ TAE running buffer. Pictures of the gels were digitally captured by the GeneGenius BioImaging System (SynGene). Cluster analysis of DGGE banding pattern of seawater samples was performed with Gel Compare v. 4.1 (Applied Maths), showing the Dice's similarity coefficients calculated for all pairs of samples. The similarity between the pairs (sub-clusters) was tested by ANOSIM.

\section{RESULTS}

\section{Hydrological and hydrodynamic features}

By analyzing the appearances of the ICCC during monthly cruises between April and September 2009 (unpubl. data) and the available satellite data from 
the same period, we hypothesize that the 2 gyre structure, typical for northern Adriatic and including the CG in the north and the AG in the south, was already present in May (Fig. S1 in the Supplement at www.int-res.com/articles/suppl/a069p193_supp.pdf). Freshened waters originating from the Po delta entered the northeastern Adriatic between 2 and 10 May. At first (10 May) both main stations SJ013 and SJ107 belonged to the AG but later (between 10 and 30 May) SJ013 became part of the CG while SJ107 remained within the AG. On days before and on the sampling date the main station SJ209 was out of the gyre region. The 2 gyre structure, with some changes in spatial extent and size, persisted in the
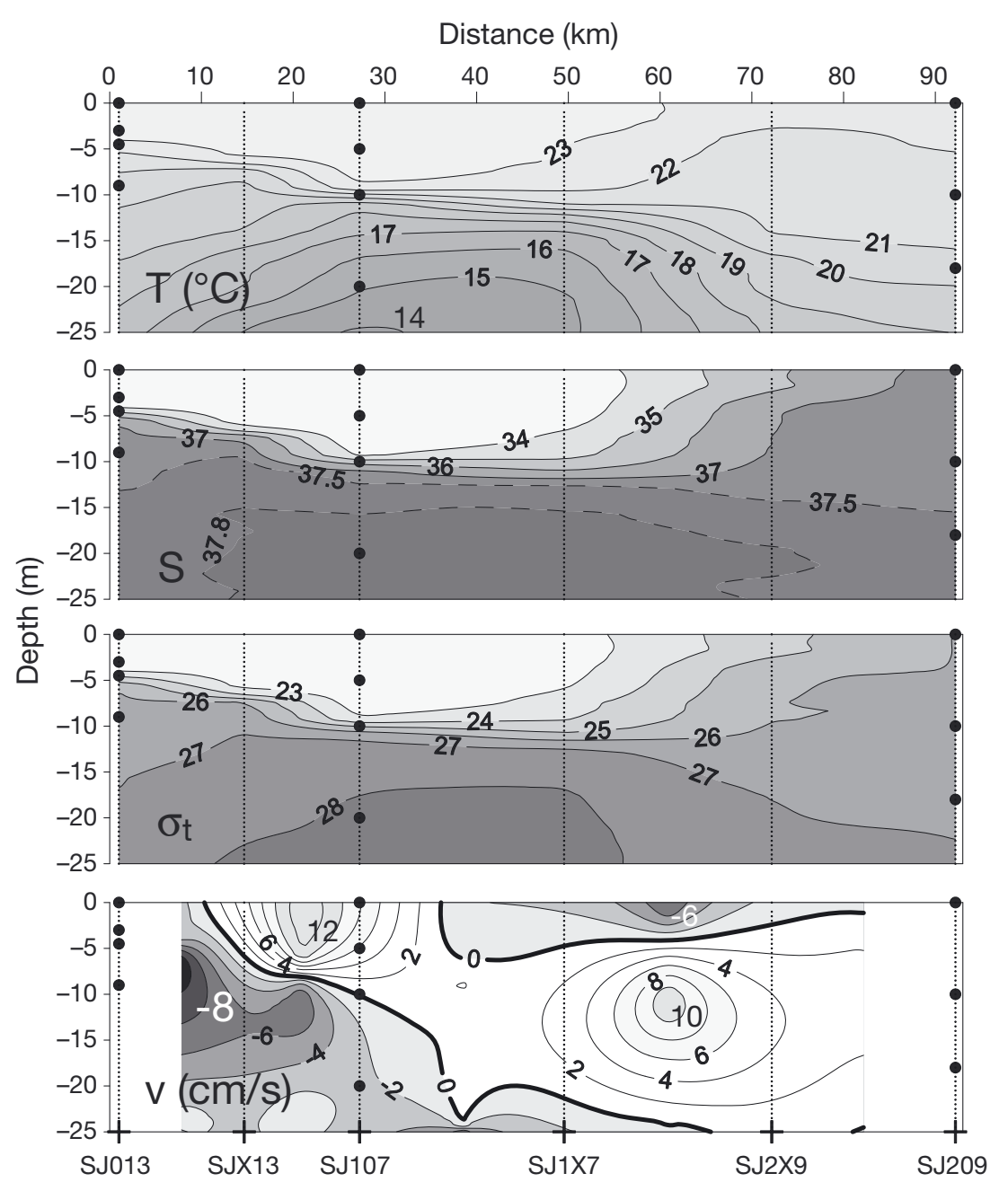

Fig. 2. Vertical distribution of temperature $(\mathrm{T})$, salinity $(\mathrm{S})$, density anomaly $\left(\sigma_{t}\right)$ values and geostrophic currents relative to the 25-dbar surface (v) at sampling stations along the transect. The horizontal scale indicates the distance between sampling points. In the bottom panel, positive values indicate currents flowing eastward towards the Istrian coast and negative values show westward flow towards the open sea. CTD casting points are indicated by vertical dotted lines and sampling points by dots region until the end of August, and disintegrated between 25 and 29 August.

Fig. 2 summarizes the hydrological characteristics at the 6 sampling stations. A pool of warm $\left(\geq 23^{\circ} \mathrm{C}\right)$, less saline (salinity $\left.<34\right)$ and less dense $\left(\sigma_{t}<\right.$ 23) water was positioned in upper layers of the section of the transect between SJ013 and SJ1X7. The pool was shallower around SJ013 $(\sim 4 \mathrm{~m})$ than around SJ107 ( 10 m). Water in the upper layer at SJ209 was less warm $\left(\sim 22^{\circ} \mathrm{C}\right)$, more saline (37 to 37.5$)$ and denser (26 to 27 ) than pool waters. According to distribution of geostrophic currents, which were of positive direction, i.e. flowing eastward towards the Istrian coast, between SJX13 and SJ107 and negative elsewhere, upper layers of main stations SJ013, SJ107 and SJ209 belonged to 3 separate circulation systems. Below the low-salinity pool area sharp gradients of temperature, salinity and density were observed, while elsewhere the hydrographic parameters changed more smoothly. Bottom layers were the coldest and the most saline part of the investigated section with a body of very dense water (temperature down to $14^{\circ} \mathrm{C}$, salinity $>37.8, \sigma_{\mathrm{t}}>28$ ) around SJ107. In layers below $10 \mathrm{~m}$, generally, currents were positive between SJ013 and SJ1X7 and negative between SJ1X7 and SJ209.

Each sampling point was characterized and labelled according to its water type, i.e. pool (P) or surrounding dense (D) water, and distinguishing between areas affected by the presence of the CG and AG, or unaffected (N) by the 2 gyres (Table 2). Thus, for example, the labels PCG1 and PCG2 were given to 2 samples of pool water affected by the CG. Differences between waters were tested for significance $(\mathrm{p}<0.05)$ by 2-sample $t$-test (Table S1 in the Supplement). Water in the pool area (P) was characterized by significantly higher temperature and lower salinity and density compared to surrounding waters (D). Locations affected by gyre presence (A), i.e. SJ013 and SJ107, were significantly less saline and less dense than at the non-affected (N) station SJ209. 


\section{Nutrient status, autotrophic and heterotrophic abundances}

Fig. 3 shows the vertical distribution of concentrations of nutrients, particles and microorganisms at Stns SJ013, SJ107 and SJ209. DIN concentrations varied widely (1.8 to $6.2 \mu \mathrm{mol} \mathrm{l}^{-1}$ ), being significantly higher in waters of lower salinity $(\mathrm{D}<\mathrm{P}, \mathrm{N}<\mathrm{A}$ ). Orthophosphates were nearly exhausted in the entire area (0.01 to $0.07 \mu \mathrm{mol} \mathrm{l}^{-1}$, data not shown). Chl a concentration (0.05 to $\left.0.35 \mu \mathrm{g} \mathrm{l}^{-1}\right)$ as well as abun-

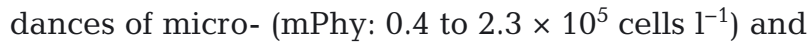

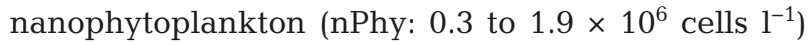
closely followed DIN concentrations (i.e. $\mathrm{D}<\mathrm{P}$ ), while picoeukaryotes ( $\mathrm{pEu}$ : 0.4 to $1.7 \times 10^{6} \mathrm{cells}^{-1}$ ) did so to a lesser extent. Synechococcus was abundant in pycnoclines, i.e. in samples DCG1 $\left(13.5 \times 10^{6}\right.$ cells $\left.\mathrm{l}^{-1}\right)$ and PAG3 $\left(27 \times 10^{6}\right.$ cells $\left.^{-1}\right)$, and in deeper non-affected waters (up to $40 \times 10^{6}$ cells l$^{-1}$ ). TEP concentrations were generally low (50.5 to $118.9 \mathrm{\mu g} \mathrm{l}^{-1}$ ) and randomly distributed. HB abundances were the

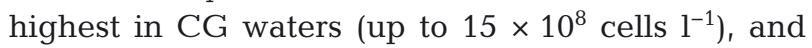
their vertical distribution correspond to that of $\mathrm{HF}$ $(\mathrm{r}=0.983, \mathrm{p}<0.05)$. In AG waters, HB (up to $8.5 \times 10^{8}$ cells $\mathrm{l}^{-1}$ ) decreased slightly with depth, while HF (up to $16 \times 10^{5}$ cells $\left.^{-1}\right)$ correlated with $\mathrm{nPhy}(\mathrm{r}=0.979$, $\mathrm{p}<0.05)$ and $\mathrm{pEu}(\mathrm{r}=0.998, \mathrm{p}<0.05)$. Between affected and non-affected waters no significant differences were observed in abundances of microorganisms, TEP and chl a concentrations.

\section{Bacterial community structure}

The cluster analysis performed on the presence/ absence matrices and the related dendrogram sepa-
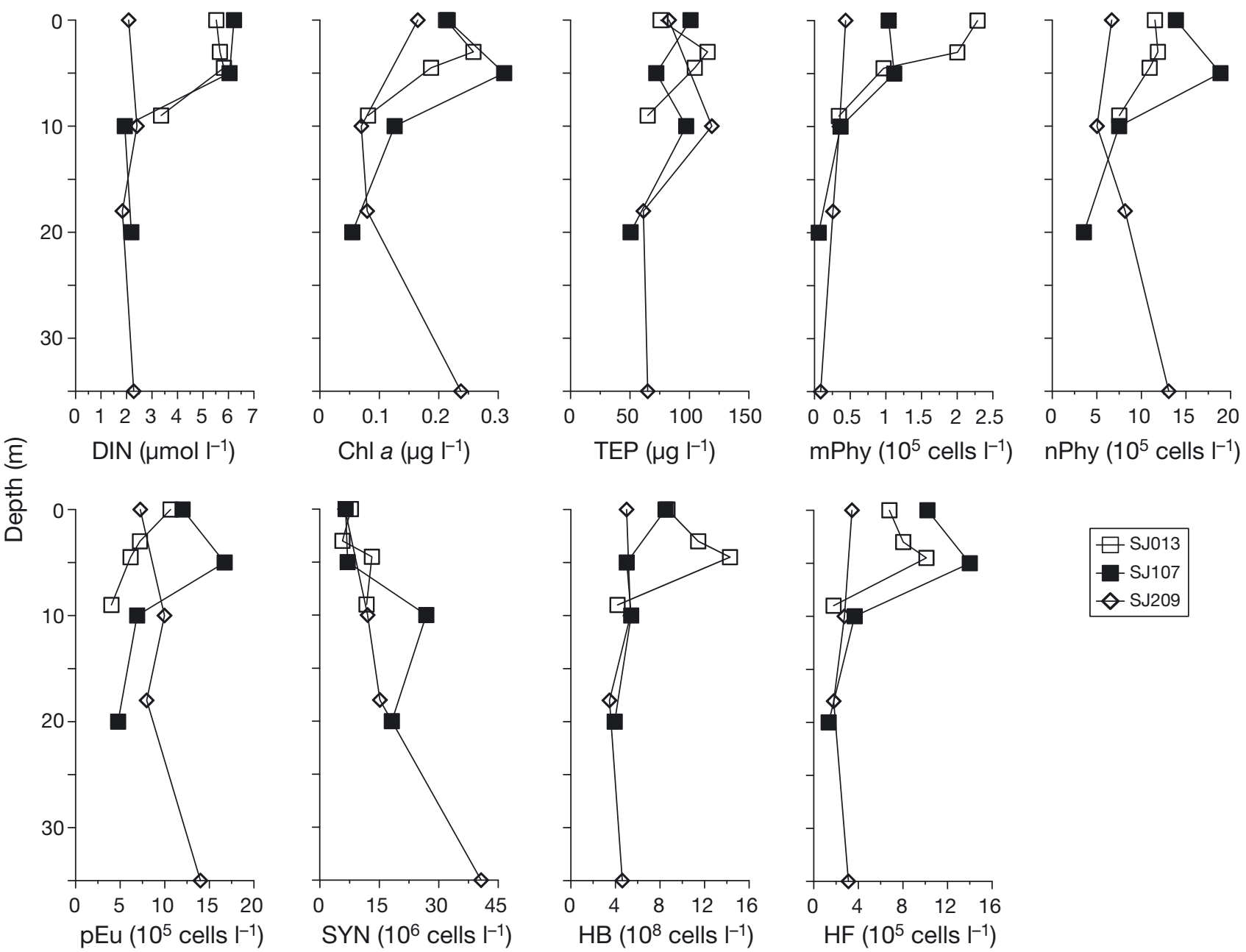

Fig. 3. Vertical distribution of concentrations of nutrients, particulates and microorganisms at Stns SJ013, SJ107 and SJ209: dissolved inorganic nitrogen (DIN), chl $a$, transparent exopolymer particles (TEP), micro-(mPhy) and nano-(nPhy) phytoplankton, picoeukaryotes (pEu), Synechococcus (SYN), heterotrophic bacteria (HB) and heterotrophic flagellates (HF) 
rated subclusters of bacterial communities according to Dice's similarity coefficients (Fig. 4). The overall similarity of adjacent layers, i.e. among sample groups PAG, PCG, and DCG, and within surface non-affected waters (samples DN1 and DN2) exceeded $90 \%$. Similarity between deeper nonaffected waters (DN3 and DN4) was lower ( 60\%). Dense water affected by the presence of AG (i.e. DAG1) remained unclustered, but was more similar to DN1 and DN2 $(\sim 53 \%)$ than to other waters. The similarity between bacterial communities of gyres (i.e. between PCG and PAG) was low ( $35 \%$ ). In contrast, the communities of the pycnoclines delimiting gyres (PAG3 and DCG1) were more similar (>60\%).

\section{Prokaryotic production and enzymatic activities}

Fig. 5 shows the vertical distribution of prokaryotic production and enzymatic activities at Stns SJ013, SJ107 and SJ209. Bulk thymidine (TdR) and cell specific leucine (Leu) incorporation rates were significantly higher in AG (15.1 to $16.4 \mathrm{pmol}^{-1} \mathrm{~h}^{-1}, 0.04$ to $0.05 \mathrm{amol} \mathrm{l}^{-1} \mathrm{~h}^{-1}$ ) than in CG (9.7 to $11.9 \mathrm{pmol} \mathrm{l}^{-1} \mathrm{~h}^{-1}$, $\left.0.03 \mathrm{amol} \mathrm{l}^{-1} \mathrm{~h}^{-1} ; \mathrm{CG}<\mathrm{AG}\right)$. Leu:TdR ratios (1.54 to 4.61) were significantly lower in AG (1.54 to 2.26) than in CG (2.93 to 3.13) (data not shown). The changes in bulk Leu incorporation with depth followed the changes in HB ( $\mathrm{r}=0.945, \mathrm{p}<0.05)$, chl $a$

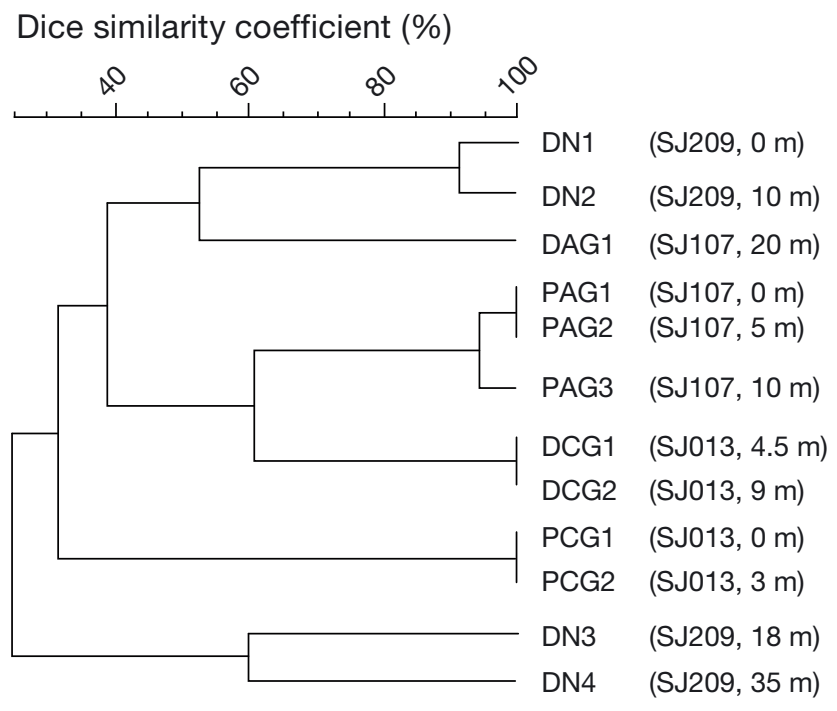

Fig. 4. Cluster analysis dendrogram of DGGE banding pattern of seawater samples from Stns SJ01, SJ107 and SJ209, showing the Dice's similarity coefficients calculated for all pairs of samples. ANOSIM $(\mathrm{R}=0.799, \mathrm{p}<0.1 \%)$ indicates that layers of similar bacterial community structures (subclusters) significantly differ between each other $(\mathrm{r}=0.905, \mathrm{p}>0.05)$ and TEP $(\mathrm{r}=0.966, \mathrm{p}<0.05)$ only in CG. Among enzymes only the activities of alkaline phosphatase (APA) were significantly higher in $P$ than in D. Cell-specific APA $\left(0.196 \mathrm{fmol} \mathrm{cell}^{-1} \mathrm{~h}^{-1}\right)$, AMA $\left(0.359 \mathrm{fmol} \mathrm{cell}^{-1} \mathrm{~h}^{-1}\right)$ and GLU $(0.133 \mathrm{fmol}$ cell $^{-1} \mathrm{~h}^{-1}$ ) were the highest in the core of $\mathrm{AG}$, i.e. PAG2. Significant activity of dissolved APA and AMA was found in DCG1 (32 and $26 \%$ of activity, respectively, in the $<3 \mu \mathrm{m}$ fraction) and in PAG2 (48 and $55 \%$, respectively) (data not shown). For dissolved AMA, significant activity was also found in dense waters of both gyres $(79 \%$ in CG and $85 \%$ in AG, data not shown). In PCG1 and PAG1, and nonaffected waters, activities of dissolved enzymes were below the detection limit $\left(<0.009 \mu \mathrm{mol} \mathrm{l}^{-1} \mathrm{~h}^{-1}\right)$. Bulk prokaryotic production and enzymatic activities were significantly higher in affected waters than in nonaffected waters $(\mathrm{N}<\mathrm{A})$.

The relationship among cell-specific prokaryotic production (Leu and TdR), enzymatic activities (APA, AMA and $\beta$-GLU), chl a (taken as a measure of autotrophic biomass) and TEP (taken as a measure of accumulated organic matter) is shown in the principal component analysis plot (Fig. 6). Variables with the highest loadings in each principal component (PC) have the greatest influence on the differentiations of the layers. PC1 explained $43.4 \%$, PC2 $25.4 \%$ and PC $316.3 \%$ of variability (eigenvalues $>1$ ). The highest loadings for positive relationship were obtained for Leu and TdR on PC1, APA and AMA on PC2 (with equal weights), and chl a on PC3. For the negative relationships the highest loadings were for TEP on PC1, Leu on PC2 and $\beta$-GLU on PC3.

The score plots separated PAG3, DCG2 and DN3 according to the influence of the higher values for the Leu and TdR combined with low chl a concentrations. The influence of the highest values for the Leu and TdR and enzymatic activities governed the outgrouping of DAG1 and PAG2, respectively. The grouping of PCG1, PCG2, PAG1 and DCG1 was due to the combined influence of higher values for APA, chl $a$ and TEP with lower values for Leu and TdR. Low rates of Leu and TdR incorporation combined with scarcely expressed enzymatic activities, determined the separation of DN1, DN2 and DN4.

\section{DISCUSSION}

The results indicate that the large gyres which typically appear in the northern Adriatic, and retain freshened waters of River Po origin, the CG and AG, were formed in spring of 2009. The size and extent of 

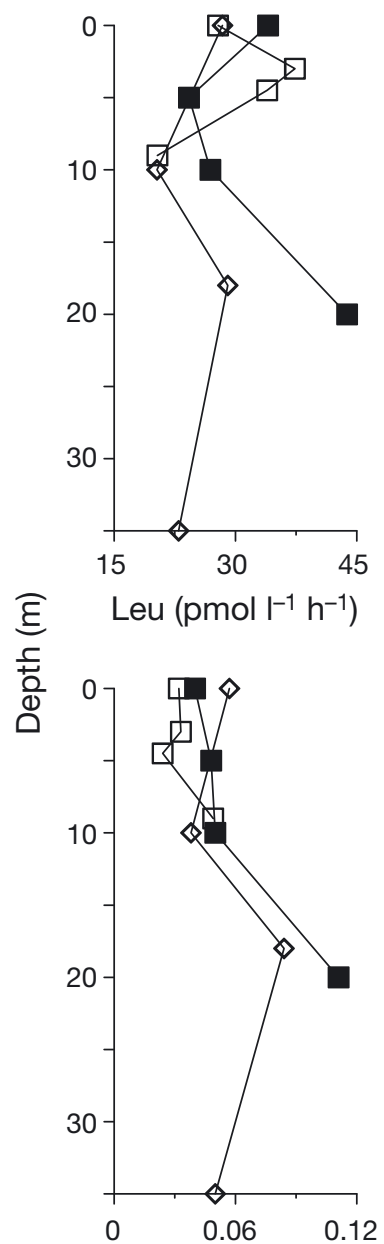

Leu $\left(\mathrm{amol} \mathrm{cell}^{-1} \mathrm{~h}^{-1}\right)$
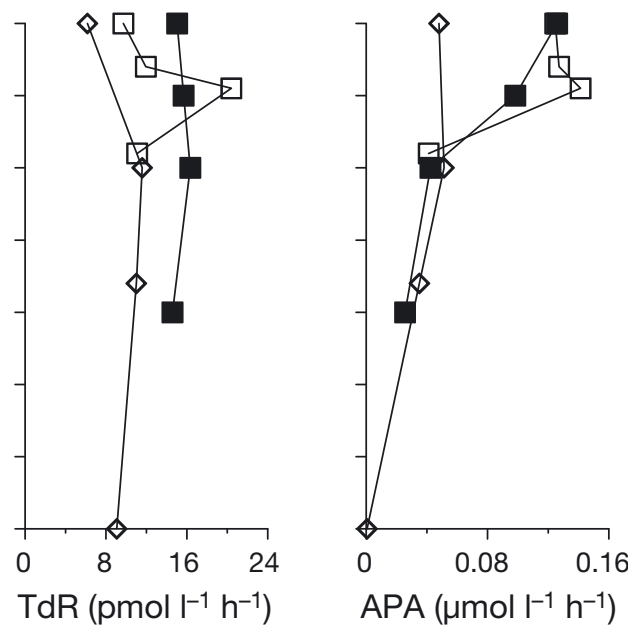

APA $\left(\mu \mathrm{mol} \mathrm{l} \mathrm{l}^{-1} \mathrm{~h}^{-1}\right)$

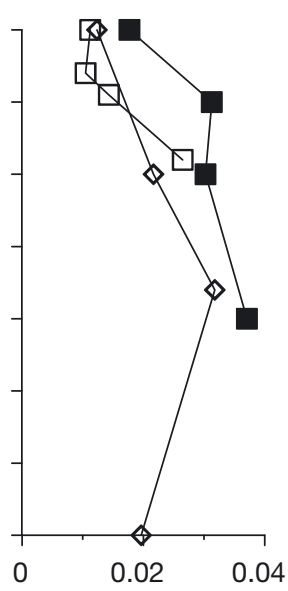

TdR (amol cell-1 $\left.\mathrm{h}^{-1}\right)$

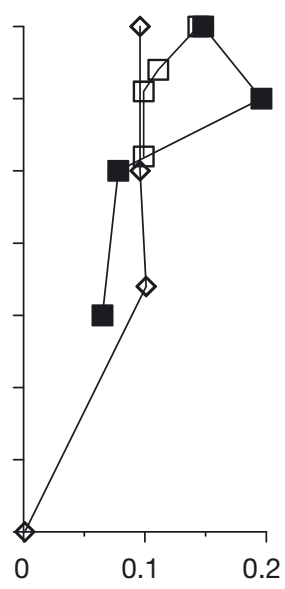

APA (fmol cell-1 $\mathrm{h}^{-1}$ )
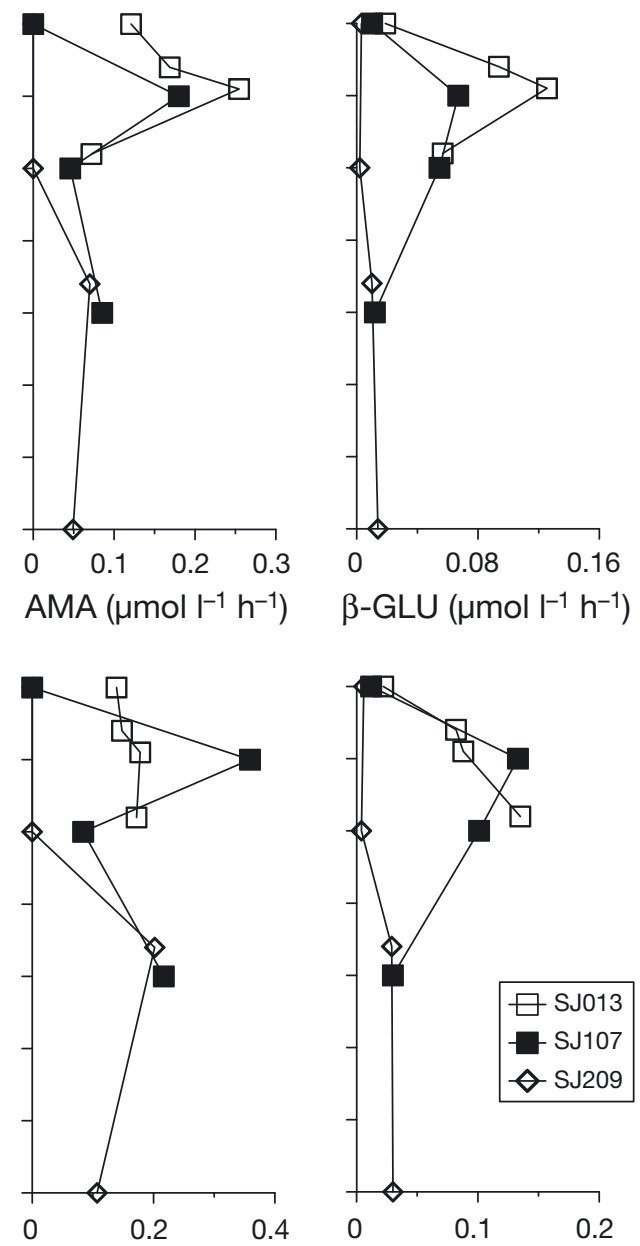

AMA (fmol cell-1 $\mathrm{h}^{-1}$ ) $\quad \beta$-GLU (fmol cell ${ }^{-1} \mathrm{~h}^{-1}$ )

Fig. 5. Vertical distribution at Stns SJ013, SJ107 and SJ209 of bulk (upper panels) and cell specific (lower panels) incorporation rates of thymidine (TdR) and leucine (Leu) and bulk and cell specific enzymatic activities of alkaline phosphatase (APA), aminopeptidase (AMA) and $\beta$-glucosidase ( $\beta$-GLU)

the gyres changed slightly over time. On the date of sampling, the upper layers (down to approximately $10 \mathrm{~m}$ ) of main stations SJ013 and SJ107 were part of the $\mathrm{CG}$ and $\mathrm{AG}$, respectively. It is possible however that the gyres extended to depths greater than $10 \mathrm{~m}$; however, in deeper layers the geostrophic approximation is less reliable and the exact depth of the gyres is impossible to obtain without direct measurements of currents. Satellite data indicate that previously both SJ013 and SJ107 were part of the AG. Thus, it is likely that residence time of water around Stn SJ107 was longer than around Stn SJ013.

In spite of the homogenous thermohaline and trophic conditions in $\mathrm{P}$ of the 2 separated circulation cells, CG and AG, a low degree of similarity between their bacterial community structures was found. This small-scale variability in the bacterial community structures within waters of similar salinity and tem- perature might be generated by heterogeneity of substrate compositions (Yokokawa et al. 2010). The seasonal variation of dissolved organic carbon (DOC) concentrations in the northern Adriatic is significant, with concentrations in summer (up to $150 \mu \mathrm{M}$ ) double those found in winter. DOC enriched in refractory compounds accumulates mainly in surface low-salinity (<37) waters (Pettine et al. 1999, Giani et al. 2005). The modification in the concentrations and nature of DOC are due to biological and mixing processes (Christaki et al. 2009). These changes in DOC are more pronounced if transit time of freshened waters from source areas into open-sea lower-salinity water structures is longer (Laghdass et al. 2010). However, since the transit times of freshened waters from the Po delta to areas in which the AG or CG are located are approximately similar, in this case the heterogeneity in organic matter between gyres could result 


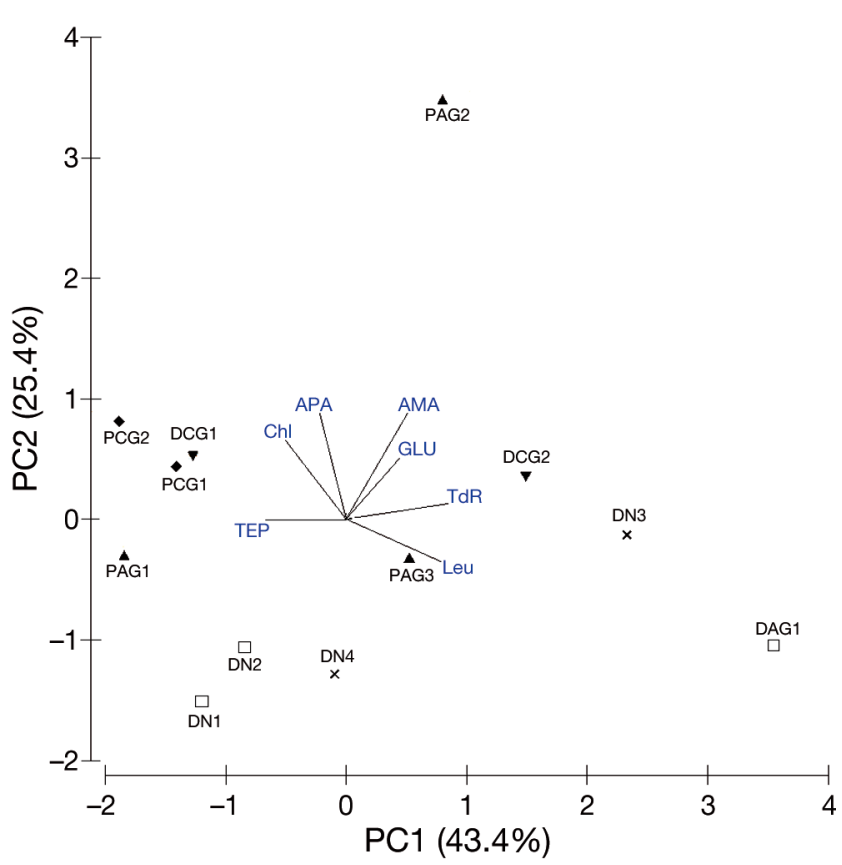

Fig. 6. Principal component analysis of samples, applied to chl a (Chl) and transparent exopolymer particle (TEP) concentrations, cell-specific incorporation of leucine (Leu) and thymidine (TdR), and bacterial cell-specific enzymatic activities of alkaline phosphatase (APA), aminopeptidase (AMA) and $\beta$-glucosidase (GLU). Identical symbols group samples with a high degree of similarity of bacterial community structure (see Fig. 4)

from differences in the residence time of freshwater residence in the 2 gyres. The observed variability in the bacterial community structures between gyres would then reflect differences in the composition of DOC.

The high autotrophic biomass (in terms of chl a) in $P$ of $A G$ and $C G$ indicated an accumulation of organic matter. Such accumulation zones are characterized by a increase in abundances of bacteria, their predators and prokaryotic production (Moran et al. 2001, Van Wambeke et al. 2004, Baltar et al. 2009). However, the increase in prokaryotic production in terms of both biomass and number of cells was associated with increased abundance of bacteria and heterotrophic flagellates in P of CG but not in P of AG. Such positive relationships observed in CG show that bacterial abundance can explain prokaryotic production to a great extent (Cole et al. 1988) and indicate that both were controlled by the same factor, namely by resource availability (Zhang et al. 2006). Comparable results in both PCG1 and PCG2 suggested that bacteria exerted similar control over produced and accumulated organic matter, giving rise to similar community structures at these 2 stations. The correlation between bacterial function and community structure suggests low levels of redundancy in functional bacterial communities, and has also been observed along a productivity gradient in the oceanic transition zone (Alonso-Sáez et al. 2007).

In contrast, very similar bacterial community structures in P of AG expressed different patterns of function. This finding suggests that the factors controlling bacterial growth in that area were different from those in P of CG. In P of AG the leucine incorporation together with bacterial abundance decreased from surface to the depth of autotrophic biomass maximum (at $5 \mathrm{~m}$ ). HF did not correlate with HB, probably due to strong bacterivory by HF and a lack of efficient predation on HF (e. g. Gasol 1994). On the other hand HF could graze on bacteria and smaller planktonic algae (Hagström et al. 1988), both abundantly present in P of AG at that time. Yet, the increased cell-specific production rates suggested that bacteria were subjected to predation, i.e. if HF controls bacterial abundance, their production would be higher (Gasol 1994). The high rates of thymidine incorporation and low Leu:TdR ratios indicated that bacteria were actively synthesizing DNA and, therefore, were highly active. As HF tends to feed preferentially on the active bacteria (del Giorgio et al. 1996, Gasol et al. 2009) it is very likely that grazing had a high impact in control of prokaryotic abundance and activities. As a consequence of the presence of active bacteria and a high autotrophic biomass, enzymatic activities were stimulated at PAG2. Aminopeptidase and glucosidase are responsible for hydrolysis of polymers, released by phosphorus-limited phytoplankton. The activities of these 2 enzymes also increase due to cell lyses (Alonso-Sáez et al. 2008). Therefore, low TEP concentration in PAG2 was caused by the intense activities of these 2 enzymes. At the same time, due to shortage of phosphates, the activity of AP was pronounced. However, the differences in prokaryotic function within P of AG were apparently not as large as the orders of magnitude difference in bulk prokaryotic activities needed to be reflected in differences in community structure (Gasol et al. 2009). The strong predation and active growth of bacteria, highly advanced in AG, was possibly in its early phase in the CG. The delay between the above-mentioned processes in the CG and AG was additionally supported by the fact that high enzymatic activity found in the dissolved fraction in the AG was larger than in the CG.

The layers around the pycnocline, DCG1 and PAG3, were characterized by moderately similar bacterial community structures. This indicates that pycnocline layers, at depths of $\sim 5 \mathrm{~m}$ in the $\mathrm{CG}$ and 
$\sim 10 \mathrm{~m}$ in the AG, were, at some point in time, connected. They were probably formed before the CG and AG became distinct circulation cells. In addition, at both DCG1 and PAG3, Synechococcus accumulated. To optimize its growth and persistence Synechococcus requires physical stability of the water column and longer water retention (Reynolds 1987). Since the abundance of Synechococcus at PAG3 was double that found at DCG1, we presumed that water retention around PAG3 was longer than around DCG1.

The community structures of D, highly dissimilar between sampling points, differed also from those in P. While communities from the upper layers resembled communities in the $\mathrm{CG}$ and $\mathrm{AG}$, those from deeper layers were likely introduced into the northern Adriatic by high-salinity oligotrophic waters from the central Adriatic. They were probably related to variable dissolved organic matter (DOM) composition and reflect the contribution of refractory compounds. Similar dissimilarities between bacterial communities have been found to be induced by the intrusion of water masses enriched in refractory DOM (Zhang et al. 2009).

The prokaryotic communities from waters affected by the presence of gyres were metabolically more active than ones from non-affected waters. Since these waters differed in salinity and not in phytoplankton biomass, it seems, in accordance with Laghdass et al. (2010), that the lower salinity waters, containing riverine discharges of organic matter, stimulated prokaryotic activities. This influence was apparently propagated into deeper layers of the waters below $\mathrm{P}$. Thus, the surface gyres CG and AG, which typically appear in the northern Adriatic and are persistent for several months or even more, appear to be 'hotspots' of prokaryotic activities. Similar evidence has been provided for cyclonic and anticyclonic mesoscale eddies in the ocean (Baltar et al. 2010).

Our study provides strong evidence based on biological, hydrographical and satellite data that the AG and CG are isolated circulation cells in which water resides for extended but different periods of time. However, further, more comprehensive studies of the positions and extents of the gyres and their role in structuring microbial communities are necessary to verify these conclusions.

Acknowledgements. We thank SCUBA diver B. Jagić for sampling, P. Krelja for CTD casting, M. Buterer for nutrient analysis and J. Jakovčević for chlorophyll determination. The work is supported by INTERREG/CARDS-PHARE Project 'Implementation of the Water Quality Monitoring in
Western Istrian Coastal Sea (Northern Adriatic)-WICOS' and by the Ministry of Science, Education and Sports of the Republic of Croatia (Projects: 0982705-2729, 0982705-2731, 0982705-2707).

\section{LITERATURE CITED}

Alonso-Sáez L, Arístegui J, Pinhassi J, Gómez-Consenau L and others (2007) Bacterial assemblage structure and carbon metabolism along a productivity gradient in the NE Atlantic Ocean. Aquat Microb Ecol 46:43-53

- Alonso-Sáez L, Vázquez-Domínguez E, Cardelús C, Pinhassi J and others (2008) Factors controlling the yearround variability in carbon flux through bacteria in a coastal marine system. Ecosystems 11:397-409

Baltar F, Arístegui J, Gasol JM, Hernández-León S, Herndl GJ (2007) Strong coast-ocean and surface-depth gradients in prokaryotic assemblage structure and activity in a coastal transition zone region. Aquat Microb Ecol 50: 63-74

- Baltar F, Arístegui J, Montero MF, Espino M, Gasol JM, Herndl GJ (2009) Mesoscale variability modulates seasonal changes in the trophic structure of nano- and picoplankton communities across the NW Africa-Canary Islands transition zone. Prog Oceanogr 83:180-188

Baltar F, Arístegui J, Gasol JM, Lekunberri I, Herndl GJ (2010) Mesoscale eddies: hotspots of prokaryotic activity and differential community structure in the ocean. ISME J 4:975-988

Caron DA (1983) A technique for the enumeration of photosynthetic and heterotrophic nanoplankton using epifluorescence microscopy, and a comparison with other procedures. Appl Environ Microbiol 46:491-498

Christaki U, Courties C, Joux F, Jeffrey WH, Neveux J, Naudin JJ (2009) Community structure and trophic role of ciliates and heterotrophic nanoflagellates in Rhone River diluted mesoscale structures (NW Mediterranean Sea). Aquat Microb Ecol 57:263-277

> Christaki U, Van Wambeke F, Lefevre D, Lagaria A and others (2011) The impact of anticyclonic mesoscale structures on microbial food webs in the Mediterranean Sea. Biogeosciences Discuss 8:185-220

Cole JJ, Findlay S, Pace ML (1988) Bacterial production in fresh and saltwater ecosystems: a cross-system overview. Mar Ecol Prog Ser 43:1-10

del Giorgio PA, Gasol JM, Vaqué D, Mura P, Agustí S, Duarte CM (1996) Bacterioplankton community structure: protists control net production and the proportion of active bacteria in a coastal marine community. Limnol Oceanogr 41:1169-1179

> Fuhrman JA, Azam F (1982) Thymidine incorporation as a measure of heterotrophic bacterioplankton production in marine surface waters: evaluation and field results. Mar Biol 66:109-120

$>$ Gasol JM (1994) A framework for the assessment of topdown vs bottom-up control of heterotrophic nanoflagellate abundance. Mar Ecol Prog Ser 113:291-300

Gasol JM, Alonso-Sáez L, Vaqué D, Baltar F, Calleja MLl, Duarte CM, Arístegui J (2009) Mesopelagic prokaryotic bulk and single-cell heterotrophic activity and community composition in the NW Africa-Canary Islands coastal-transition zone. Prog Oceanogr 83:189-196

Giani M, Savelli F, Berto D, Zangrando V, Ćosović B, Vojvodić V (2005) Temporal dynamics of dissolved and par- 
ticulate organic carbon in the northern Adriatic Sea in relation to mucilage events. Sci Total Environ 353:126-138 Hagström Å, Azam F, Andersson A, Wikner J, Rassoulzadegan F (1988) Microbial loop in an oligotrophic pelagic marine ecosystem: possible roles of cyanobacteria and nanoflagellates in the organic fluxes. Mar Ecol Prog Ser 49:171-178

Hoppe HG (1983) Significance of exoenzymatic activities in the ecology of brackish water: measurements by means of methylumbelliferyl-substrates. Mar Ecol Prog Ser 11: 299-308

Hoppe HG, Kim SJ, Gocke K (1988) Microbial decomposition in aquatic environments:combined process of extracellular enzyme activity and substrate uptake. Appl Environ Microbiol 54:784-790

Ivančić I, Radić T, Lyons DM, Fuks D, Precali R, Kraus R (2009) Alkaline phosphatase activity in relation to nutrient status in the northern Adriatic Sea. Mar Ecol Prog Ser 378:27-35

Kirchman D, K'Nees E, Hodson R (1985) Leucine incorporation and its potential as a measure of protein synthesis by bacteria in natural aquatic systems. Appl Environ Microbiol 49:599-607

Krajcar V (2003) The climatology of geostrophic currents in the northern Adriatic. Geofizika 20:105-114

Krajcar V (2004) A new method for estimating climatological temperature and salinity fields in the northern Adriatic from historic data. Acta Adriat 45:131-143

Kuzmić M, Janeković I, Book JW, Martin PJ, Doyle JD (2007) Modelling the northern Adriatic double-gyre response to intense Bora wind: a revisit. J Geophys Res 111:C03S13, doi:10.1029/2005JC003377

Laghdass M, West NJ, Batailler N, Caparros J and others (2010) Impact of lower salinity waters on bacterial heterotrophic production and community structure in the offshore NW Mediterranean Sea. Environ Microbiol Rep 2:761-769

> Legendre L, Rassoulzadegan F (1996) Food-web mediated export of biogenic carbon in oceans: hydrodynamic control. Mar Ecol Prog Ser 145:179-193

Lyons DM, Supić N, Smodlaka N (2007) Geostrophic circulation patterns in the northeastern Adriatic Sea and the effects of air-sea coupling: May-September 2003. J Geophys Res 112:C03S08, doi:10.1029/2005JC003100

Moran XAG, Taupier-Letage I, Vázquez-Domínguez E, Ruiz S, Arin L, Raimbault P, Estrada M (2001) Physical-biological coupling in the Algerian Basin (SW Mediterranean): influence of mesoscale instabilities on the biomass and production of phytoplankton and bacterioplankton. Deep-Sea Res I 48:405-437

Passow U, Alldredge AL (1995) A dye binding assay for the spectrophotometric measurement of transparent exopolymer particles (TEP). Limnol Oceanogr 40: 1326-1335

Editorial responsibility: Josep Gasol, Barcelona, Spain
Pettine M, Patrolecco L, Manganelli M, Capri S, Farrace MG (1999) Seasonal variations of dissolved organic matter in the northern Adriatic Sea. Mar Chem 64:153-169

$>$ Porter KG, Feig YS (1980) The use of DAPI for identification and counting aquatic microflora. Limnol Oceanogr 25: 943-984

Reynolds CS (1987) Cyanobacterial water blooms. In: Callow P (ed) Advances in botanical research, Vol 13. Academic Press, London, p 17-143

> Sieburth JM, Smetacek V, Lenz J (1978) Pelagic ecosystem structure: heterotrophic compartments of the plankton and their relationship to plankton size fractions. Limnol Oceanogr 23:1256-1263

Smith DC, Azam F (1992) A simple, economical method for measuring bacteria protein synthesis rates in seawater using ${ }^{3} \mathrm{H}$-leucine. Mar Microb Food Webs 6:107-114

Strickland JDH, Parsons TR (1972) A practical handbook of seawater analysis. Bull Fish Res Board Can 167:1-310

Supić N, Orlić M, Degobbis D (2000) Istrian coastal counter current and its year-to-year variability. Estuar Coast Shelf Sci 51:385-397

Supić N, Kraus R, Kuzmić M, Paschini E, Precali R, Russo A, Vilibić I (2012) Predictability of northern Adriatic winter conditions. J Mar Syst 90:42-57

Throndsen J (1978) Preservation and storage In: Sournia A (ed) Phytoplankton manual. Monographs on oceanographic methodology 6. UNESCO, Paris, p 68-74

Utermöhl H (1958) Zur Vervollkommnung der quantitativen Phytoplankton-Methodik. Mitt Int Ver Theor Angew Limnol 9:1-38

Van Wambeke F, Lefèvre D, Prieur L, Sempéré R, Bianchi M, Oubelkheir K, Bruyant F (2004) Distribution of microbial biomass, production, respiration, dissolved organic carbon and factors controlling bacterial production across a geostrophic front (Almeria-Oran, SW Mediterranean Sea). Mar Ecol Prog Ser 269:1-15

- Van Wambeke F, Ghiglione JF, Nedoma J, Mével G, Raimbault P (2009) Short scale variations in nutrients, ectoenzymatic activities and bottom-up effects on bacterial production and community structure during late summer-autumn transition in the open NW Mediterranean Sea. Biogeosci Discuss 6:687-727

> Yokokawa T, De Corte D, Sintes E, Herndl GJ (2010) Spatial patterns of bacterial abundance, activity and community composition in relation to water masses in the eastern Mediterranean Sea. Aquat Microb Ecol 59:185-195

> Zhang Y, Jiao N, Cottrell MT, Kirchman DL (2006) Contribution of major bacterial groups to bacterial biomass production along a salinity gradient in the South China Sea. Aquat Microb Ecol 43:233-241

Zhang Y, Sintes E, Chen J, Zhang Y, Dai M, Jiao N, Herndl GJ (2009) Role of mesoscale cyclonic eddies in the distribution and activity of Archaea and Bacteria in the South China Sea. Aquat Microb Ecol 56:65-79

Submitted: August 18, 2012; Accepted: April 2, 2013 Proofs received from author(s): June 6, 2013 